\title{
SYNTHESIS, ANTIMICROBIAL ACTIVITIES AND COMPUTATIONAL STUDIES OF SOME OXAZOLONE DERIVATIVES
}

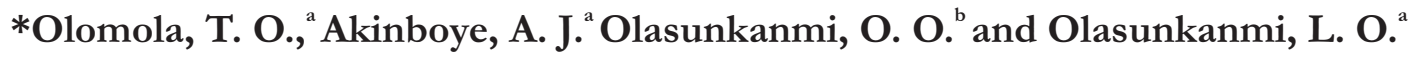

a Department of Chemistry, Faculty of Science, Obafemi Awolowo University, Ile-Ife 220005, Nigeria.

${ }^{b}$ Department of Microbiology, Faculty of Science, Obafemi Awolowo University, Ile-Ife 220005, Nigeria. *Corresponding author: tolomola@oauife.edu.ng

(Received: $19^{\text {th }}$ December, 2017; Accepted: $8^{\text {th }}$ February, 2018)

\section{ABSTRACT}

Synthesis of the oxazolone derivatives was achieved by the condensation of aromatic aldehydes with $N$-acetyl glycine in the presence of acetic anhydride and anhydrous sodium acetate. A total of six oxazolones were synthesized and characterized using ${ }^{1} \mathrm{H}-\mathrm{NMR},{ }^{13} \mathrm{C}-\mathrm{NMR}$ and FT-IR spectroscopic techniques. The synthesized compounds were screened for their in vitro antibacterial and antifungal activities using streptomycin and ampicillin as control. The result showed that some of the compounds demonstrate good antibacterial activities against specific bacterial strains and moderate activities against other bacterial strains. The compounds did not show any sensitivity against the tested fungal strains. The quantitative structure-antibacterial activity relationship was studied using some quantum chemical parameters with the aid of Spartan 10 (V1.0.1) and XLSTAT (add-in) software. A good correlation was observed between the antibacterial activity of the compounds and the calculated quantum chemical descriptors.

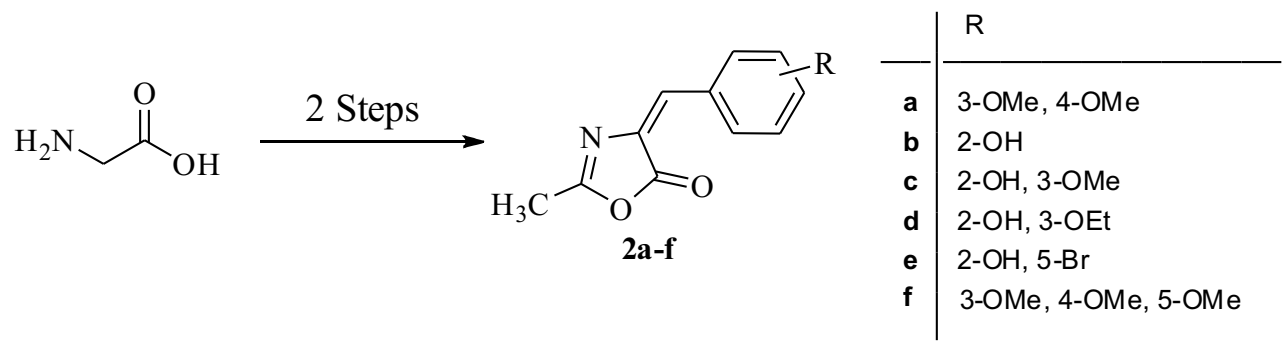

Keywords: oxazolones; $N$-acetyl glycine; antibacterial activity; chemical descriptors.

\section{INTRODUCTION}

Increasing resistance of human pathogens to chemotherapeutic agents is a major problem. Recent efforts geared towards developing more effective antimicrobial agents are faced with the challenge of toxicity and undesirable side effects. Therefore, there is the need to search for more potent and less toxic antimicrobial drugs. Mostly, nitrogen, sulphur and oxygen containing five and six membered heterocyclic compounds have been very significant in the field of medicinal chemistry (Aaglawe et al., 2003).

Oxazolones are important class of heterocyclic compounds which possess an interestingly broad spectrum of biological activities such as antimicrobial (Desai et al., 2009; Siddiqui et al., 2001; Brownlee and Woodbine, 1948), antiinflammatory (Abdel-Aty, 2009, Argade et al., 2008), anticancer (Gaenzler and Corbo, 2007, Sanchez et al., 2006), anti-HIV (Siddiqui et al., 2010; Witvrouw et al., 1999; Pinto et al., 1996), antiangiogenic (Sierra et al., 2002), anticonvulsant (Madkour, 2002), antitumor, antagonist, sedative (Tikdari et al., 2008; Khan et al., 2006; Mesaik et al., 2004) and cardiotonic activity (Schnettler et al., 1987). These activities are attributed to their various substitution patterns at C-2 and C-4 positions (Abdel-Aty, 2009). Jadomycin B for example, is an antifungal antibiotic produced by the bacterium Streptomyces venezuelae ISP 5230 (Rix et al., 2004).

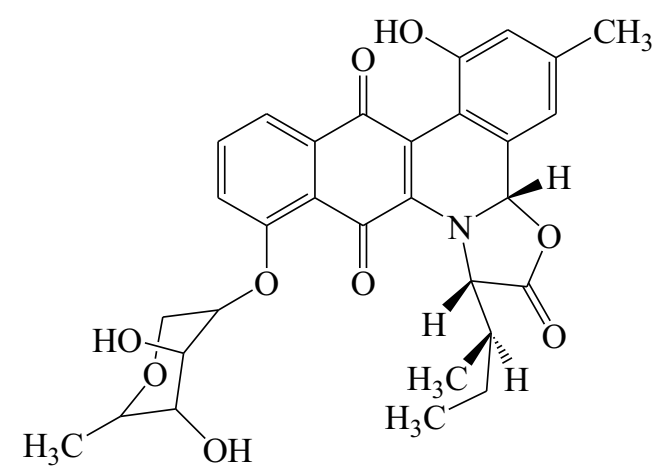

Jadomycin B 
Natural and synthetic oxazolones are used as synthons for the construction of various alkaloid skeletons, immunomodulators and biosensors (Ozturk et al., 2008; Khan et al., 2006; Bourotte et al., 2004; Fearnley and Market, 2002) or photosensitive composition devices for proteins (Tikdari et al., 2008; Pasha et al., 2007; Mesaik et al., 2004). They also exhibit promising photophysical and photochemical activities (Palcut, 2009; Bourotte et al., 2004; Jung et al., 1996), which makes them find usage in semiconductor devices such as electrophotographic photoreceptors and in non-linear optical materials (Murthy et al., 2010; Ozturk et al., 2007; Ozturk et al., 2006).

Researches that bother on understanding the basis of biological activities of compounds have witnessed tremendous advancement with the use of quantum chemical calculations and quantitative structure activity relationship (QSAR). Quantum chemical calculations and QSAR analysis have proven useful in correlating biological activities with molecular structures of compounds (Alam et al., 2011; GonzAlez-Diaz and Prado-Prado, 2008; Bhattacharjee et al., 2002; Lipinski et al., 2001; Alcaraz et al., 2000). Studies that employ quantum chemical studies to unravel the relative strengths of a series of drugs or active chemical agents against certain microorganisms and relating such to some quantum chemical parameters are found in literature (Alam et al., 2011; Bhattacharjee et al., 2002; Alcaraz et al., 2000). In continuation of our search for biologically active heterocycles, we herein report the evaluation of the antimicrobial properties and quantum mechanical studies of some oxazolones. These compounds though not novel, were synthesized from $N$-acetyl glycine for the present study.

\section{EXPERIMENTAL}

Nuclear magnetic resonance (NMR) spectra were recorded on Biospin $600 \mathrm{MHz}$ spectrometer at $303 \mathrm{~K}$ in DMSO- $d_{6}$ or $\mathrm{CDCl}_{3}$ and calibrated using solvent signals $\delta_{\mathrm{H}}: 7.26$ for residual $\mathrm{CDCl}_{3}$, and 2.50 for residual DMSO- $d_{6}, \delta_{\mathrm{C}}: 77.0\left(\mathrm{CDCl}_{3}\right)$ and $39.5\left(\mathrm{DMSO}-d_{6}\right)$. Infrared (IR) spectra were recorded on a Perkin-Elmer spectrum 100 FT-IR spectrometer and were run neat. Melting points were determined using a Gallenkamp melting point apparatus and are uncorrected. Thin layer chromatography was carried out on a pre-coated
Merck silica gel $60 \mathrm{~F}_{254}$ plates using a mixture of ethylacetate and hexane (4:1) as the eluting solvent and viewed under UV light (254 / $365 \mathrm{~nm})$ or following exposure to iodine vapour.

\section{Chemistry \\ Synthesis of $\mathrm{N}$-acetyl glycine, 1}

To a solution of glycine $(0.75 \mathrm{~g}, 10 \mathrm{mmol})$ dissolved in $10 \% \mathrm{NaOH}$ solution $(10 \mathrm{~mL})$, acetyl bromide $(1.5 \mathrm{~mL}, 20 \mathrm{mmol})$ was added in portions and the solution allowed to stir continuously for 1 h. The solution was cooled by adding a few grams of crushed ice and few drops of concentrated hydrochloric acid was added to acidify the mixture. The white solid obtained was filtered, washed with ice cold water, dried and then recrystallized from ethanol to afford $N$-acetyl glycine as a crystalline white solid(1.33 g, 85\%), m.p. 207-209 ${ }^{\circ} \mathrm{C}$ (lit. 206-208 ${ }^{\circ} \mathrm{C}$ ) (Mokale et al., 2014).IR spectrum (neat, $\left.v_{\max } \mathrm{cm}^{-1}\right): 3348(\mathrm{O}-\mathrm{H})$, 2941 ( $\mathrm{sp}^{3}-\mathrm{CH}$ stretching frequency), $1717(\mathrm{C}=\mathrm{O}$ stretching frequency of amide), 1540 (N-H bending vibration), 1580 and 1439 (symmetric and the asymmetric stretch of the carboxyl group). ${ }^{1} \mathrm{H}$ NMR (600 MHz, DMSO- $\left.d_{6}\right): \delta 1.85\left(3 \mathrm{H}, \mathrm{s}, \mathrm{CH}_{3}\right)$, $3.73\left(2 \mathrm{H}, \mathrm{d}, J=6.1 \mathrm{~Hz}, \mathrm{CH}_{2}\right), 8.15(1 \mathrm{H}, \mathrm{t}, J=6.1$ $\mathrm{Hz}, \mathrm{N}-\mathrm{H}$ proton). ${ }^{13} \mathrm{C}$ NMR $(150 \mathrm{MHz}, \mathrm{DMSO}-$ $\left.d_{6}\right): \delta 22.7\left(\mathrm{CH}_{3}\right), 41.1\left(\mathrm{CH}_{2}\right), 170.3(\mathrm{NH}-\mathrm{C}=\mathrm{O})$ and $171.9(\mathrm{HO}-\mathrm{C}=\mathrm{O})$.

\section{Synthesis of 4-(benzylidene)-2-methyl- oxazol-5 $(4 \mathrm{H})$-ones, $2 \mathrm{a}-\mathrm{f}$}

A mixture of $N$-acetyl glycine, $1(8.5 \mathrm{mmol})$, the required aldehyde (17.1 mmol), anhydrous sodium acetate $(8.4 \mathrm{mmol})$ and acetic anhydride $(34.0$ mmol) was refluxed for $2 \mathrm{~h}$ on a water bath with constant stirring at $100{ }^{\circ} \mathrm{C}$. The resulting mixture was left in refrigerator overnight. The solid obtained was filtered, washed with cold water, dried and recrystallized from ethanol to afford the desired product.

\section{4-(3,4-Dimethoxybenzylidene)-2-methyl- oxazol-5(4H)-one, 2 a}

An orange solid (1.16 g, 55\%), m.p. $165-167^{\circ} \mathrm{C}$ (CAS Registry Number 41888-65-7). IR spectrum (neat, $\left.v_{\max } \mathrm{cm}^{-1}\right): 3080 \quad\left(\mathrm{sp}^{2}-\mathrm{CH}\right.$ stretching frequency), 2832-2964 ( $\mathrm{sp}^{3}-\mathrm{CH}$ stretching frequency), $1756(\mathrm{C}=\mathrm{O}$ stretching frequency of five membered ring lactone), $1654 \quad(\mathrm{C}=\mathrm{C}$ 
stretching frequency), $1573(\mathrm{C}=\mathrm{N}$ stretching frequency), 1590 and 1463 (Ar-C stretching frequencies), 1166 and 1257 (C-O stretching frequencies of lactone). ${ }^{1} \mathrm{H}$ NMR $(600 \mathrm{MHz}$, $\left.\mathrm{CDCl}_{3}\right): \delta 2.39\left(3 \mathrm{H}, \mathrm{s}, \mathrm{CH}_{3}\right), 3.95\left(6 \mathrm{H}, \mathrm{s}, 2 \times \mathrm{OCH}_{3}\right)$, $6.91(1 \mathrm{H}, \mathrm{d}, J=1.8 \mathrm{~Hz}, \mathrm{Ar}-\mathrm{H}), 7.09(1 \mathrm{H}, \mathrm{s}, \mathrm{C}=\mathrm{CH})$, $7.51(1 \mathrm{H}, \mathrm{dd}, J=1.8 \mathrm{~Hz}, 8.4 \mathrm{~Hz}, \mathrm{Ar}-\mathrm{H}), 7.94(1 \mathrm{H}$, $\mathrm{d}, J=8.4 \mathrm{~Hz}, \mathrm{Ar}-\mathrm{H}) .{ }^{13} \mathrm{CNMR}\left(150 \mathrm{MHz}, \mathrm{CDCl}_{3}\right)$ : $15.8\left(\mathrm{CH}_{3}\right), 56.1\left(2 \times \mathrm{OCH}_{3}\right), 111.0,114.0,126.6$, 127.5, 130.7, 131.8, 149.3, 152.1, (C=C, Ar-C), $165.0(\mathrm{C}=\mathrm{N})$ and $168.3(\mathrm{C}=\mathrm{O})$.

\section{4-(2-Hydroxybenzylidene)-2-methyl-oxazol- $5(4 \mathrm{H})$-one, $2 \mathrm{~b}$}

A pale yellow solid (1.35 g, 78\%), m.p. $147-149^{\circ} \mathrm{C}$ (lit.150-158 ${ }^{\circ} \mathrm{C}$ ) (Mokale et al., 2014). IR spectrum (neat, $\left.\nu_{\max } \mathrm{cm}^{-1}\right): 3419(\mathrm{OH}$ stretching vibration), $3002\left(\mathrm{sp}^{2}-\mathrm{CH}\right.$ stretching frequency), $2962\left(\mathrm{sp}^{3}-\mathrm{CH}\right.$ stretching frequency), $1738(\mathrm{C}=\mathrm{O}$ stretching frequency of five membered ring lactone), 1621 ( $\mathrm{C}=\mathrm{C}$ stretching frequency), 1556 and 1493 (Ar-C stretching frequencies), 1074 and 1257 (C-O stretching frequencies of lactone). ${ }^{1} \mathrm{H}$ NMR (600 $\left.\mathrm{MHz}_{2} \mathrm{CDCl}_{3}\right): \delta 2.24\left(3 \mathrm{H}, \mathrm{s}, \mathrm{CH}_{3}\right), 7.29-7.32(2 \mathrm{H}$, overlapping signals, Ar- $\mathrm{H}), 7.43(1 \mathrm{H}, \mathrm{t}, J=7.2 \mathrm{~Hz}$, Ar-H), $7.50(1 \mathrm{H}, \mathrm{d}, J=7.7 \mathrm{~Hz}, \mathrm{Ar}-\mathrm{H}), 8.11(1 \mathrm{H}, \mathrm{bs}$, Ar- $\mathrm{OH}), 8.66(1 \mathrm{H}, \mathrm{s}, \mathrm{C}=\mathrm{CH}) .{ }^{13} \mathrm{C}$ NMR $(150$ $\left.\mathrm{MHz}, \mathrm{CDCl}_{3}\right): \delta 24.7\left(\mathrm{CH}_{3}\right), 158.737(\mathrm{C}=\mathrm{N})$, 149.847, 129.6, 127.7, 125.1,123.9, 123.24 119.80, $116.30(\mathrm{C}=\mathrm{C}, \mathrm{Ar}-\mathrm{C})$ and $169.4(\mathrm{C}=\mathrm{O})$.

\section{4-(2-Hydroxy-3-methoxybenzylidene)-2-} methyl-oxazol-5(4H)-one, $2 \mathrm{c}$

A pale yellow solid $(1.23 \mathrm{~g}, 62 \%)$, m.p. $152-154^{\circ} \mathrm{C}$. IR spectrum (neat, $\left.\nu_{\max } \mathrm{cm}^{-1}\right): 3332(\mathrm{OH}$ stretching vibration), 3097 ( $\mathrm{sp}^{2}-\mathrm{CH}$ stretching frequency), 2843 and 2941 ( $\mathrm{sp}^{3}-\mathrm{CH}$ stretching frequency), $1706(\mathrm{C}=\mathrm{O}$ stretching frequency of five membered ring lactone), 1674 ( $\mathrm{C}=\mathrm{C}$ stretching frequency), 1606 and 1473 (Ar-C stretching frequencies), 1576 ( $\mathrm{C}=\mathrm{N}$ stretching frequency), 1246 and 1183 (C-O stretching frequencies). ${ }^{1} \mathrm{H}$ $\operatorname{NMR}\left(600 \mathrm{MHz}_{\mathrm{CDCl}}\right): \delta 2.23\left(3 \mathrm{H}, \mathrm{s}, \mathrm{CH}_{3}\right), 3.95$ $\left(3 \mathrm{H}, \mathrm{s}, \mathrm{OCH}_{3}\right), 6.99(1 \mathrm{H}, \mathrm{d}, J=8.0 \mathrm{~Hz}, \mathrm{Ar}-\mathrm{H}), 7.08$ $(1 \mathrm{H}, \mathrm{d}, J=8.0 \mathrm{~Hz}, \operatorname{Ar}-\mathrm{H}), 7.23(1 \mathrm{H}, \mathrm{t}, J=8.0 \mathrm{~Hz}$, Ar-H), $8.11(1 \mathrm{H}$, br s, Ar-OH $), 8.63(1 \mathrm{H}, \mathrm{s}$, $\mathrm{C}=\mathrm{CH}) .{ }^{13} \mathrm{C}$ NMR $\left(150 \mathrm{MHz}, \mathrm{CDCl}_{3}\right), 24.0\left(\mathrm{CH}_{3}\right)$, $55.5\left(\mathrm{OCH}_{3}\right), 111.0,118.7,119.9,122.6,123.6$, 124.4, 138.7, 146.3 (C=C, $\mathrm{Ar}-\mathrm{C}), 157.7(\mathrm{C}=\mathrm{N})$ and $168.7(\mathrm{C}=\mathrm{O})$.
4-(2-Hydroxy-3-ethoxybenzylidene)-2methyl-oxazol-5(4H)-one, $2 \mathrm{~d}$

A grey solid (1.52 g, 72\%), m.p. $118-121^{\circ} \mathrm{C}$ (CAS Registry Number 1334664-50-4). IR spectrum (neat, $\nu_{\max } \mathrm{cm}^{-1}$ ): 3318 (OH stretching frequency), $3074\left(\mathrm{sp}^{2}-\mathrm{CH}\right.$ stretching frequency), $2848\left(\mathrm{sp}^{3}-\mathrm{CH}\right.$ stretching frequency), $1719(\mathrm{C}=\mathrm{O}$ stretching frequency of five membered ring lactone), 1658 $(\mathrm{C}=\mathrm{C}$ stretching frequency), 1605 and 1476 (Ar-C stretching frequencies), $1572(\mathrm{C}=\mathrm{N}$ stretching frequency), 1217 and 1167 (C-O stretching frequencies). ${ }^{1} \mathrm{H}$ NMR (600 $\left.\mathrm{MHz}, \mathrm{CDCl}_{3}\right): \delta$ $1.50\left(3 \mathrm{H}, \mathrm{t}, J=7.0 \mathrm{~Hz}, \mathrm{OCH}_{2} \mathrm{CH}_{3}\right), 2.24(3 \mathrm{H}, \mathrm{s}$, $\left.\mathrm{CH}_{3}\right), 4.18\left(2 \mathrm{H}, \mathrm{q}, J=7.0 \mathrm{~Hz}, \mathrm{OCH}_{2} \mathrm{CH}_{3}\right), 6.99$ $(1 \mathrm{H}, \mathrm{dd}, J=8.1 \mathrm{~Hz}, 1.0 \mathrm{~Hz}$ Ar-H), 7.07 (1H, dd, $J$ $=7.8 \mathrm{~Hz}, 1.0 \mathrm{~Hz}$ Ar-H), $7.20(1 \mathrm{H}, \mathrm{t}, J=8.0 \mathrm{~Hz}, \mathrm{Ar}-$ $\mathrm{H}), 8.10(1 \mathrm{H}$, brs, Ar-OH), $8.63(1 \mathrm{H}, \mathrm{s}, \mathrm{C}=\mathrm{CH})$. ${ }^{13} \mathrm{C}$ NMR (150 MHz, $\left.\mathrm{CDCl}_{3}\right): 14.9\left(\mathrm{OCH}_{2} \mathrm{CH}_{3}\right)$, $24.9\left(\mathrm{CH}_{3}\right), 65.0\left(\mathrm{OCH}_{2} \mathrm{CH}_{3}\right), 113.1,119.4,120.8$, 123.6, 124.2, 125.1, 139.8, 146.5, (C=C, ArC), $158.6(\mathrm{C}=\mathrm{N})$ and $169.5(\mathrm{C}=\mathrm{O})$.

\section{4-(2-Hydroxy-5-bromobenzylidene)-2-} methyloxazol-5(4H)-one, $2 \mathrm{e}$

A pale yellow solid (1.87 g, 78\%), m.p. $223-225^{\circ} \mathrm{C}$ (CAS Registry Number 280140-75-2). IR spectrum (neat, $\left.\nu_{\max } \mathrm{cm}^{-1}\right): 3343(\mathrm{OH}$ stretching frequency), 3094 ( $\mathrm{sp}^{2}-\mathrm{CH}$ stretching frequency), 2890-2985 ( $\mathrm{sp}^{3}-\mathrm{CH}$ stretching frequency), 1753 $(\mathrm{C}=\mathrm{O}$ stretching frequency of five membered ring lactone), 1682 ( $\mathrm{C}=\mathrm{C}$ stretching frequency), 1607 and 1470 (Ar-C stretching frequencies), 1578 (C=N stretching frequency), 1242 and 1184 (C-O stretching frequencies). ${ }^{1} \mathrm{H}$ NMR $(600 \mathrm{MHz}$, $\left.\mathrm{CDCl}_{3}\right): \delta 2.25\left(3 \mathrm{H}, \mathrm{s}, \mathrm{CH}_{3}\right), 7.21(1 \mathrm{H}, \mathrm{d}, J=8.8 \mathrm{~Hz}$, Ar-H), $7.52(1 \mathrm{H}, \mathrm{dd}, J=8.8 \mathrm{~Hz}, 2.3 \mathrm{~Hz}$ Ar-H), 7.65 $(1 \mathrm{H}, \mathrm{d}, J=2.3 \mathrm{~Hz}, \mathrm{Ar}-\mathrm{H}), 8.07$ (1 H, br s, Ar-OH), $8.59(1 \mathrm{H}, \mathrm{s}, \mathrm{C}=\mathrm{CH}) .{ }^{13} \mathrm{C}$ NMR $\left(150 \mathrm{MHz}, \mathrm{CDCl}_{3}\right)$, $25.0\left(\mathrm{CH}_{3}\right), 116.7,120.2,123.6,124.3,125.5$, 128.1, 130.0, 150.2, (C=C, Ar-C),159.1 (C=N), and $169.8(\mathrm{C}=\mathrm{O})$.

\section{$4-(3,4,5-$ Trimethoxybenzylidene $)-2$ - methyloxazol-5(4H)-one, $2 \mathrm{f}$}

A yellow solid $\left(1.42 \mathrm{~g}, 60 \%\right.$ ), m.p. $135-137^{\circ} \mathrm{C}$ (lit. 136-138 ${ }^{\circ} \mathrm{C}$ ) (Mokale et al., 2014).IR spectrum (neat, $\left.\nu_{\max } \mathrm{cm}^{-1}\right): 3102 \quad\left(\mathrm{sp}^{2}-\mathrm{CH}\right.$ stretching frequency), 2942 ( $\mathrm{sp}^{3}-\mathrm{CH}$ stretching frequency), $1763(\mathrm{C}=\mathrm{O}$ stretching frequency of five membered ring lactone), 1658 ( $\mathrm{C}=\mathrm{C}$ stretching 
frequency), 1605 and 1470 (Ar-C stretching frequencies), 1587 ( $\mathrm{C}=\mathrm{N}$ stretching frequency), 1252 and 1155 (C-O stretching frequencies). ${ }^{1} \mathrm{H}$ NMR $\left(600 \mathrm{MHz}, \mathrm{CDCl}_{3}\right): \delta 2.40\left(3 \mathrm{H}, \mathrm{s}, \mathrm{CH}_{3}\right), 3.91$ $\left(9 \mathrm{H}, \mathrm{s}, 3 \times \mathrm{OCH}_{3}\right), 7.05(1 \mathrm{H}, \mathrm{s}, \mathrm{C}=\mathrm{CH}), 7.40(2 \mathrm{H}, \mathrm{s}$, Ar-H). ${ }^{13} \mathrm{C}$ NMR (150 MHz, $\left.\mathrm{CDCl}_{3}\right): 15.9\left(\mathrm{CH}_{3}\right)$, 56.4 and $61.2\left(\mathrm{OCH}_{3}\right), 109.8,128.7,131.6,140.1$, 141.2, 153.4 $(\mathrm{C}=\mathrm{C}, \mathrm{Ar}-\mathrm{C}), 165.8(\mathrm{C}=\mathrm{N})$ and168.1 $(\mathrm{C}=\mathrm{O})$.

\section{Antimicrobial Activities Microorganisms}

The standard bacteria of National Collection for Industrial Bacteria (NCIB), Clinical Isolate from Blood (CIB) and Locally Isolated Organisms (LIO) used in the research work were obtained from the Department of Microbiology, Obafemi Awolowo University, Ile-Ife. These include Stapbylococcus aureus (NCIB 8588), Bacillus cereus (NCIB 6349), Streptococcus pneumonia (CIB), Enterococcus faecalis (NCIB 775), Corynebacterium pyogenes (LIO), Pseudomonas aeruginosa (NCIB 950), Proteus vulgaris (LIO), Klebsiella pneumoniae (NCIB 418), Escherichia coli (NCIB 86) and Shigella sp (LIO).

The fungal strains include Trichophyton mentagrophytes, Aspergillus niger, Candida albicans, Aspergillus glacus and Aspergillus flavus.

\section{Sensitivity Testing}

The antimicrobial activities of the compounds were determined using the agar-well diffusion method. The bacterial isolates were first grown in nutrient broth for $18 \mathrm{~h}$ before use, while the fungal isolates were allowed to grow on potato dextrose agar medium (PDA) at $25^{\circ} \mathrm{C}$ until they sporulated. The fungal spores were harvested after sporulation by pouring mixture of sterile glycerol and distilled water to the surface of the plate which were then scraped with a sterile glass rod. The harvested fungal spores and the bacterial isolates were standardized before use. One hundred microliter of the standardized bacterial suspension was evenly spread on Mueller-Hinton agar using a glass spreader while the same volume of the fungal spore suspension was spread on potato dextrose agar. Wells were then bored into the agar media using a sterile $6 \mathrm{~mm}$ cork borer and the wells filled with the solution of the compound $(10 \mathrm{mg} / \mathrm{mL})$ taking care not to allow spillage of the solution to the surface of the agar medium.
The plates were allowed to stand on the laboratory bench for $1 \mathrm{~h}$ to allow proper diffusion of the compounds into the media. The bacterial isolates were thereafter incubated at $37^{\circ} \mathrm{C}$ for $24 \mathrm{~h}$ after which they were observed for zones of inhibition. Plates containing fungal isolates were incubated at $25^{\circ} \mathrm{C}$ for $96 \mathrm{~h}$ and afterwards observed for zones of inhibition (Irobi et al., 1994; Russell and Furr, 1977). The effects of the compounds on the test bacterial isolates were compared with those of ampicillin and streptomycin standard antibiotics at a concentration of $1 \mathrm{mg} / \mathrm{mL}$. The effect of the compounds on fungal isolates was compared with nystatin at a concentration of $1 \mathrm{mg} / \mathrm{mL}$. The antimicrobial tests were performed in compliance with Clinical \& Laboratory Standards Institute (CLSI) guidelines.

\section{Determination of Minimum Inhibitory Concentration (MIC)}

The minimum inhibitory concentration (MIC) is defined as the lowest concentration of a compound inhibiting the visible growth of any microorganism. Two-fold dilutions of the compounds were prepared and $2 \mathrm{~mL}$ aliquot of different concentrations of the solutions were added to $18 \mathrm{~mL}$ of pre-sterilized molten nutrient agar at $40^{\circ} \mathrm{C}$ to give a final concentration range of 0.31 to $10.0 \mathrm{mg} / \mathrm{mL}$. The medium was then poured into sterile Petri dishes and allowed to set. The surfaces of the media were allowed to dry under a laminar flow before streaking with $18 \mathrm{~h}$ old bacterial cultures. The $6 \mathrm{~mm}$ cork borer was used to bore wells in the already solidified media inoculated with the microorganisms. Different concentrations of compounds were dispensed into each well. The preparation was left to diffuse before incubating at $37^{\circ} \mathrm{C}$ for $24 \mathrm{~h}$ for the bacterial strains (Akinpelu and Kolawole, 2004).

\section{Determination of Minimum Bactericidal Concentration (MBC)}

The MBC test determines the lowest concentration at which an antimicrobial agent will kill a particular microorganism. The MBC is determined using a series of steps, undertaken after a Minimum Inhibitory Concentration (MIC) test has been completed. Samples for the MBC were taken from line of streak on MIC plates without visible growth and then streaked onto extract-free freshly prepared nutrient agar 
medium plates. The plates were incubated at $37^{\circ} \mathrm{C}$ for $48 \mathrm{~h}$. The MBC was taken as the lowest concentration of the extract that did not allow any bacterial growth on the surface of the agar plates at the end of the $48 \mathrm{~h}$ incubation period (Cushnie et al., 2007).

\section{Computational details}

Initial geometries of the molecules were obtained by modelling the molecular structures of the compounds using the GaussView 5.0 software. Gas phase geometry optimization and force constant calculations were carried out using the density functional theory (DFT) method. The adopted DFT model comprises the Becke three parameter hybrid functional together with LeeYang-Parr correlation functional (B3LYP) (Becke, 1993; Lee et al., 1988; Parr and Yang, 1984), used in conjunction with $6-311+(\mathrm{d}, \mathrm{p})$ basis set. Acceptable predictions of equilibrium molecular geometries and quantum chemical parameters of various organic compounds have been previously obtained by using the B3LYP functional together with different Pople-type basis sets (Dibetsoe et al., 2015; Brovarets et al., 2014; Samijlenko et al., 2010; Lozynski et al., 1998). The 6-311+(d,p) basis set has also been successfully used to describe the energies of a number of organic molecules using different basis sets (Wodrich et al., 2007). Absence of imaginary data in the vibrational frequencies of the optimized structures confirmed that they correspond to true energy minima. All the calculations were carried out with the aid of Gaussian 09 software suite (Frisch et al., 2009). Frontier molecular orbital (FMO) energies including the highest occupied molecular orbital energy $\left(\mathrm{E}_{\text {номо }}\right)$ and lowest unoccupied molecular orbital energy $\left(\mathrm{E}_{\text {LUмо }}\right)$ were obtained and used to derive other selected quantum chemical descriptors such as the energy gap (E) and global hardness ( $)$ as (Dibetsoe et al., 2015):

$\mathrm{E}=\mathrm{E}_{\mathrm{LUMO}}-\mathrm{E}_{\text {номо }}($ Becke, 1993)

$\eta=-\frac{1}{2}\left(E_{\text {номо }}-E_{L U M O}\right)($ Parr and Yang, 1984)

Descriptors such as octanol-water partition coefficient $(\log \mathrm{P})$, polarizability $(\propto)$, number of hydrogen bond donor (HBD), and number of hydrogen bond acceptor (HBA) were obtained by carrying out single point energy calculations on the optimized structures of the molecules using
Spartan $10($ V1.0.1) software.

Quantitative structure activity relationship (QSAR) analyses were performed in order to relate the observed zone of inhibition of the molecules with composite quantum chemical descriptors. Since the compounds are not effective against the entire bacteria isolates considered, average values of zone of inhibition for Eschericia coli and Pseudomonas aeruginosa for which all the compounds were found responsive were used as representative variables for the QSAR analyses. Linear QSAR model equations that show the dependence of antimicrobial activity of the compounds on molecular quantum chemical descriptors were obtained with the aid of XLSTAT (add-in) software (Addinsoft, XLSTAT, 2006).

\section{RESULTS AND DISCUSSION}

\section{Chemistry}

The reaction of acetyl bromide with glycine in $10 \%$ sodium hydroxide solution afforded $N$ acetylglycine. The reaction followed a nucleophilic acyl substitution in which the lone pair of electrons on the amino group of the glycine serves as the nucleophile which attacks the carbonyl group of the acetyl bromide to afford an alkoxide intermediate. The intermediate group then rearranges with loss of bromine to give $\mathrm{N}$ acetylglycine.

Various oxazolone derivatives, 2 a-f were synthesized by condensation of different aromatic aldehydes with in-situ generated oxazolone, formed by the cyclodehydration of $N$ acetylglycine, using acetic anhydride as the cyclodehydrating agent. The mechanism involves the formation of a mixed anhydride by the substitution of the carboxylic acid proton by an acetyl group. The mixed anhydride then undergoes an intermolecular rearrangement expelling acetic acid in the process to form the oxazolone. Condensation with various aromatic aldehydes is thought to follow a base-catalysed aldol condensation in which the acetate ion abstracts an acidic proton from the oxazolone to form the enolate ion, which can undergo tautomerism. The enolate, a nucleophile then adds to the electrophilic carbon of the aromatic aldehyde to form an alkoxide ion. Protonation of 
the alkoxide ion gives the $\beta$-hydroxyl product

which undergoes dehydration to afford various

oxazolone derivatives, 2 a-f.)

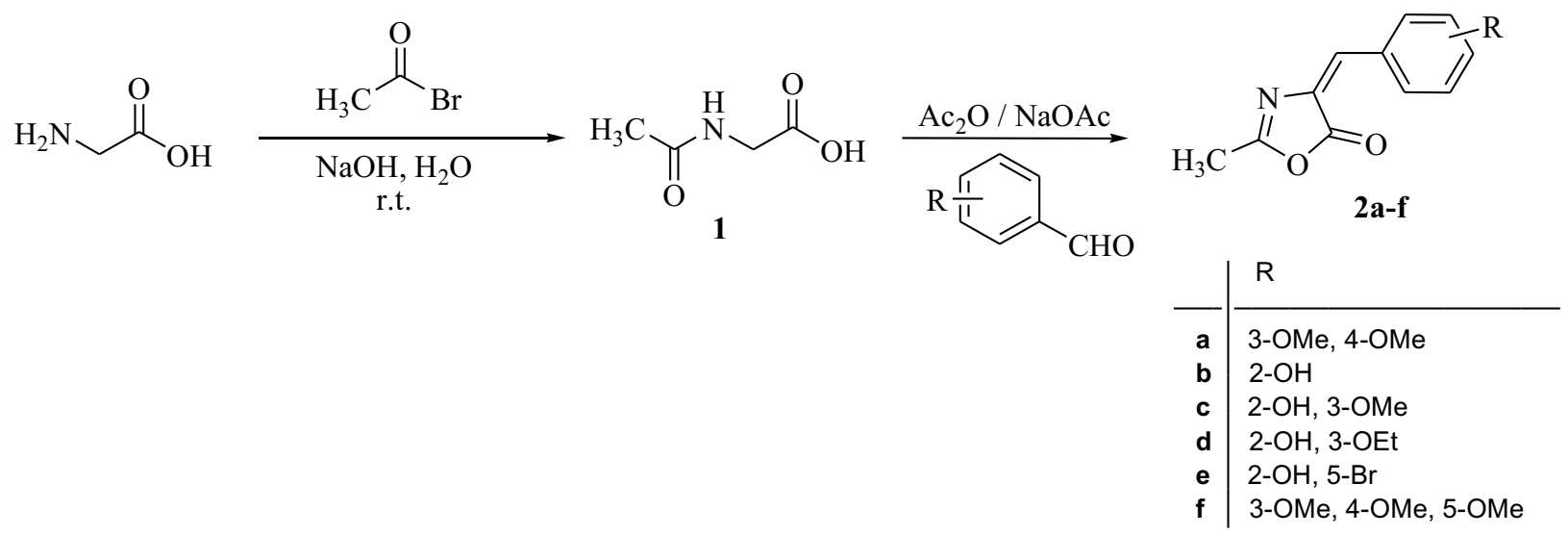

Scheme 1: Synthesis ofoxazolone derivatives

The ${ }^{1} \mathrm{H}$ NMR spectrum of $4-(3,4-$ dimethoxybenzylidene)-2-methyl-oxazol-5(4H)one, 2 a shows the methyl protons resonating as a singlet at $\delta 2.39$ and the methoxy protons at $\delta 3.95$. The non-aromatic methine proton resonates as a singlet at $\delta 7.09$ due to inductive effect of the electronegative nitrogen atom and the magnetic anisotropy constituted by the $\pi$ electrons in the olefin. Aromatic protons showed peaks between $\delta$ 6.92 and 7.94. The ${ }^{13} \mathrm{C}$ NMR spectrum of the same compound showed the methyl carbon resonating at $\delta 15.84$, methoxy carbon at $\delta 56.14$, and accounts for all other expected signals.
The ${ }^{1} \mathrm{H}$ NMR spectrum of $2 \mathbf{b}$ shows the methyl protons resonating as a singlet at $\delta 2.24$ and the aromatic hydroxyl proton as a broad singlet at $\delta$ 8.11. The non-aromatic methine proton resonates as a singlet at 8.66 which is higher than what is observed in $\mathbf{2 a}$. This is attributed to hydrogen bonding between the non-aromatic methine proton and the phenolic oxygen atom, in addition to the magnetic anisotropy constituted by the $\pi$ electrons in the olefin. The same trend was also observed in compounds $2 \mathrm{c}-\mathrm{e}$ due to the presence of the hydroxyl group on the phenyl ring. Aromatic protons of $\mathbf{2} \mathbf{b}$ showed peaks between $\delta$ 7.29 and 7.50 . 
Table 1: Result of the Antimicrobial Activity / Sensitivity Testing on Gram-positive and Gramnegative Bacteria at $10 \mathrm{mg} / \mathrm{mL}$ concentration with the Zones of Inhibition (mm)

\begin{tabular}{llllllllll}
\hline \hline Bacterial Isolate & $\mathbf{1}$ & 2a & 2b & 2c & 2d & 2e & 2f & Amp & Strep \\
\hline \hline E. coli (-ve) & 13 & 18 & 16 & 16 & 16 & 15 & 15 & 16 & 22 \\
Ps. aeruginosa(-ve) & 10 & 12 & 11 & 12 & 11 & 11 & 14 & 17 & 16 \\
P.vulgaris(-ve) & 14 & 0 & 0 & 0 & 0 & 0 & 10 & 15 & 25 \\
K. pneumoniae(-ve) & 10 & 9 & 0 & 0 & 0 & 0 & 0 & 0 & 20 \\
Shigella sp(-ve) & 0 & 0 & 0 & 0 & 0 & 0 & 0 & 19 & 21 \\
Staph. aureus(+ve) & 12 & 10 & 0 & 0 & 0 & 0 & 9 & 17 & 27 \\
C.pyogenes (+ve) & 10 & 0 & 0 & 0 & 0 & 0 & 0 & 21 & 28 \\
S.pneumoniae $(+\mathrm{ve})$ & 0 & 14 & 16 & 13 & 14 & 16 & 14 & 16 & 17 \\
E. faecalis $(+\mathrm{ve})$ & 0 & 0 & 0 & 0 & 0 & 0 & 0 & 0 & 25 \\
B. cereus $(+\mathrm{ve})$ & 11 & 10 & 9 & 0 & 0 & 0 & 9 & 0 & 22 \\
\hline \hline
\end{tabular}

Amp: Ampicillin, Strep: Streptomycin, -ve: Gram-negative bacteria, +ve: Gram-positive bacteria

Table 2: Minimum Inhibitory Concentration $(\mathrm{mg} / \mathrm{mL})$ of the synthesized compounds against Gram-positive and Gram-negative Bacterial Strains at $10 \mathrm{mg} / \mathrm{mL}$

\begin{tabular}{llllllllll}
\hline \hline Bacterial Isolate & $\mathbf{1}$ & 2a & 2b & 2c & 2d & 2e & 2f & Amp & Strep \\
\hline \hline E. coli (-ve) & 2.5 & 1.25 & 5 & 1.25 & 5 & 0.31 & 2.5 & 0.25 & 0.03125 \\
Ps. aeruginosa(-ve) & 2.5 & 1.25 & 5 & 5 & 5 & 0.625 & 2.5 & 0.0625 & 0.125 \\
P. vulgaris (-ve) & 2.5 & $\mathrm{ND}$ & $\mathrm{ND}$ & $\mathrm{ND}$ & $\mathrm{ND}$ & $\mathrm{ND}$ & $\mathrm{ND}$ & 0.125 & 0.25 \\
K. pneumoniae (-ve) & 2.5 & 1.25 & $\mathrm{ND}$ & $\mathrm{ND}$ & $\mathrm{ND}$ & $\mathrm{ND}$ & $\mathrm{ND}$ & 0 & 0.5 \\
Staph. aureus(+ve) & 2.5 & 5 & $\mathrm{ND}$ & $\mathrm{ND}$ & $\mathrm{ND}$ & $\mathrm{ND}$ & 5 & 0.0625 & 0.03125 \\
C.pyogenes(+ve) & 2.5 & $\mathrm{ND}$ & $\mathrm{ND}$ & $\mathrm{ND}$ & $\mathrm{ND}$ & $\mathrm{ND}$ & $\mathrm{ND}$ & 0.125 & 0.25 \\
S. pneumoniae(+ve) & $\mathrm{ND}$ & 1.25 & 5 & 5 & 5 & 0.31 & 5 & 0.125 & 0.25 \\
B. cereus (+ve) & 2.5 & 1.25 & 5 & $\mathrm{ND}$ & $\mathrm{ND}$ & $\mathrm{ND}$ & 5 & 0 & 0.0625 \\
\hline \hline
\end{tabular}

Amp: Ampicillin, Strep: Streptomycin, ND: Not Detected, +ve: Gram-positive bacteria, -ve: Gramnegative bacteria 
Table 3: Minimum Bactericidal Concentration $(\mathrm{mg} / \mathrm{mL})$ of the synthesized compounds against Gram-positive and Gram-negative Bacterial Strains

\begin{tabular}{lllllllllr}
\hline \hline Bacterial Isolate & $\mathbf{1}$ & 2a & 2b & 2c & 2d & 2e & 2f & Amp & Strep \\
\hline \hline E. coli (-ve) & 5 & 2.5 & 5 & 2.5 & 10 & 0.625 & 2.5 & 1.0 & 0.0625 \\
Ps. aeruginosa(-ve) & 5 & 5 & 10 & 10 & 10 & 2.5 & 5 & 0.125 & 0.25 \\
P.vulgaris (-ve) & 5 & ND & ND & ND & ND & ND & ND & 0.25 & 0.5 \\
K. pneumoniae (-ve) & 5 & 2.5 & ND & ND & ND & ND & ND & ND & 1.0 \\
Staph. aureus(+ve) & 5 & 10 & ND & ND & ND & ND & 10 & 0.125 & 0.0625 \\
C. pyogenes(+ve) & 5 & ND & ND & ND & ND & ND & ND & 0.25 & 0.50 \\
S. pneumoniae(+ve) & ND & 2.5 & 10 & 10 & 10 & 5 & 10 & 0.50 & 0.50 \\
B. cereus (+ve) & 5 & 2.5 & 10 & ND & ND & ND & 10 & ND & 0.125 \\
\hline \hline
\end{tabular}

Amp: Ampicillin, Strep: Streptomycin, ND: Not Detected, +ve: Gram-positive bacteria, -ve: Gramnegative bacteria

Table 4:Minimum Bactericidal Concentration (MBC)/ Minimum Inhibitory Concentration (MIC) Ratio

\begin{tabular}{|c|c|c|c|c|c|c|c|c|c|}
\hline \multirow{2}{*}{$\begin{array}{l}\text { Bacterial } \\
\text { Isolate }\end{array}$} & 1 & $2 a$ & $2 \mathrm{~b}$ & $2 \mathrm{c}$ & $2 \mathrm{~d}$ & $2 \mathrm{e}$ & $2 f$ & Amp & Strep \\
\hline & $\begin{array}{c}\text { MBC/MIC } \\
\text { Ratio }\end{array}$ & $\begin{array}{c}\text { MBC/MIC } \\
\text { Ratio }\end{array}$ & $\begin{array}{c}\text { MBC/MIC } \\
\text { Ratio }\end{array}$ & $\begin{array}{c}\text { MBC/MIC } \\
\text { Ratio }\end{array}$ & $\begin{array}{c}\text { MBC/MIC } \\
\text { Ratio }\end{array}$ & $\begin{array}{c}\text { MBC/MIC } \\
\text { Ratio }\end{array}$ & $\begin{array}{c}\text { MBC/MIC } \\
\text { Ratio }\end{array}$ & $\begin{array}{c}\text { MBC/MIC } \\
\text { Ratio }\end{array}$ & $\begin{array}{c}\text { MBC/MIC } \\
\text { Ratio }\end{array}$ \\
\hline E. coli (-ve) & $2 /$ Bactericidal & 2/ Bactericidal & $0 /$ Bactericidal & 2 / Bactericidal & 2/ Bactericidal & 2 / Bactericidal & $0 /$ Bactericidal & $\begin{array}{c}4 / \\
\text { Bactericidal }\end{array}$ & $\begin{array}{c}2 / \\
\text { Bactericidal }\end{array}$ \\
\hline $\begin{array}{l}\text { Ps. aeruginosa (- } \\
\text { ve) }\end{array}$ & 2 / Bactericidal & 4 / Bactericidal & 2 / Bactericidal & 2 / Bactericidal & 2 / Bactericidal & 4 / Bactericidal & 2 / Bactericidal & $\begin{array}{c}2 / \\
\text { Bactericidal }\end{array}$ & $\begin{array}{c}2 / \\
\text { Bactericidal }\end{array}$ \\
\hline P. vulgaris (-ve) & 2 / Bactericidal & - & - & - & - & - & - & $\begin{array}{c}2 / \\
\text { Bactericidal }\end{array}$ & $\begin{array}{c}2 / \\
\text { Bactericidal }\end{array}$ \\
\hline $\begin{array}{l}\text { K. pneumoniae (- } \\
\text { ve) }\end{array}$ & 2/ Bactericidal & 2 / Bactericidal & - & - & - & - & - & - & $\begin{array}{c}2 / \\
\text { Bactericidal }\end{array}$ \\
\hline $\begin{array}{l}\text { Staph. } \\
\text { aureus }(+\mathrm{ve})\end{array}$ & $2 /$ Bactericidal & 2/ Bactericidal & - & - & - & - & 2/ Bactericidal & $\begin{array}{c}2 / \\
\text { Bactericidal }\end{array}$ & $\begin{array}{c}2 / \\
\text { Bactericidal }\end{array}$ \\
\hline C. pyogenes $(+\mathrm{ve})$ & 2/ Bactericidal & - & - & - & - & - & - & $\begin{array}{c}2 / \\
\text { Bactericidal }\end{array}$ & $\begin{array}{c}2 / \\
\text { Bactericidal }\end{array}$ \\
\hline $\begin{array}{l}\text { S. } \\
\text { pneumoniae }(+\mathrm{ve})\end{array}$ & - & 2 / Bactericidal & 2 / Bactericidal & 2 / Bactericidal & 2 / Bactericidal & $\begin{array}{c}16 / \\
\text { Bacteriostatic }\end{array}$ & 2 / Bactericidal & $\begin{array}{c}4 / \\
\text { Bactericidal }\end{array}$ & $\begin{array}{c}2 / \\
\text { Bactericidal }\end{array}$ \\
\hline B. cereus (+ve) & 2 / Bactericidal & 2 / Bactericidal & 2 / Bactericidal & - & - & - & 2 / Bactericidal & - & $\begin{array}{c}2 / \\
\text { Bactericidal }\end{array}$ \\
\hline
\end{tabular}

\section{Antimicrobial Activity:}

Table 1 shows the results of the sensitivity test (as zones of inhibition in $\mathrm{mm}$ ) of the synthesized compounds against ampicillin and streptomycin. Some of the compounds exhibited a measure of broad spectrum antibacterial activity for different Gram-positive and -negative bacterial isolates tested such as $\mathbf{1}$ and $\mathbf{2 a}$ while others were not as broad in sensitivity but at least all the compounds were sensitive to one Gram-positive and one Gram-negative bacteria at the concentration used.

Table 2 shows the minimum inhibitory concentration values of the tested compounds and this shows that $2 \mathrm{e}$ has better activity against Escherichia coli than one reference drug, ampicillin and a comparable activity with another reference drug, streptomycin. Also, compound $2 \mathrm{e}$ showed a better activity than both ampicillin and streptomycin against Streptococcus pneumoniae.
Compounds $\mathbf{2 a}$ and $\mathbf{2 c}$ showed better activity than ampicillin against Escherichia coli, compound $\mathbf{1}$ showed similar activity with ampicillin against Escherichia coli and similar activity with streptomycin against Proteus vulgaris and Corynebacterium pyogenes. Compound $2 \mathrm{a}$ had a comparable activity with streptomycin against Pseudomonas aeruginosa, better activity than streptomycin against Klebseilla pneumoniae and similar activity with ampicillin against Streptococcus pneumoniae.

As observed from the minimum bactericidal concentration, compound $2 \mathrm{e}$ also demonstrated a better activity than the standard, ampicillin but comparable with streptomycin against Escherichia coli (Table 3). The MBC/MIC ratio of the oxazolone derivatives was determined to show the bacteriostatic or bactericidal effect of obtained derivatives (Table 4). The mode/mechanism of 
action is most likely by cell wall disruption leading to leakages of cell components like protein, $\mathrm{Na}^{+}$ ions and $\mathrm{K}^{+}$ions.

The compounds did not show any sensitivity against the tested fungal strains at $10 \mathrm{mg} / \mathrm{mL}$.

\section{Computational Studies}

In an attempt to correlate the antimicrobial activities of the synthesized compounds with their reactivity indices, selected reactivity parameters of the compounds were obtained after their geometries had been fully optimized in the gas phase. Gas phase optimized structures of the molecules are shown as part of the supporting information(Figure S1). Selected reactivity indices and other theoretically derived parameters are listed in Table 5. As stated earlier, only the results of antibacterial activities of the molecules against E. coli (-ve) and Ps. aeruginosa (-ve) bacterial isolates (Table 1) were used as the reference for correlations between experimental and theoretical data.

Molecular reactivity is often related to the frontier molecular orbital (FMO) energies, namely highest occupied molecular orbital energy $\left(\mathrm{E}_{\text {номо }}\right)$ and lowest unoccupied molecular orbital energy $\left(\mathrm{E}_{\mathrm{LUMO}}\right) . \mathrm{E}_{\text {номо }}$ is widely used as a measure of the readiness of a molecule to donate its HOMO electron(s) to the appropriate orbital of an accepting specie, while $\mathrm{E}_{\mathrm{LUMO}}$ is a measure of propensity of a molecule to accept electron from suitable orbital of a donor molecule (Dibetsoe et al., 2015). In this regard, the higher the $\mathrm{E}_{\text {номо }}$ and/or the lower the $\mathrm{E}_{\mathrm{LUmO}}$, the more reactive a molecule. All the synthesized molecules $(\mathbf{2} \mathbf{a}-\mathbf{f})$ showed higher $\mathrm{E}_{\text {номо }}$ and lower $\mathrm{E}_{\mathrm{LU} \text { мо }}$ than 1 (i.e. $\mathrm{N}$-acetylglycine), which suggests higher reactivity of $2 \mathbf{a}-\mathbf{f}$ than 1 . This agrees with the higher antimicrobial activities of $\mathbf{2} \mathbf{a}-\mathbf{f}$ against E. coli (-ve) and Ps. aeruginosa (-ve) compared to 1 .

The energy gap $(\Delta \mathrm{E})$, which is the difference between $\mathrm{E}_{\mathrm{LUMO}}$ and $\mathrm{E}_{\text {номо }}$ is a gauge of electronic stability and reactivity of a molecule. In addition to $\mathrm{E}_{\text {номо }}$ and $\mathrm{E}_{\mathrm{Lumo}}$, the synthesized molecules $(\mathbf{2 a}-\mathbf{f})$ showed lower $\Delta \mathrm{E}$ than $\mathbf{1}$, which further suggests higher reactivity (higher antimicrobial activity) of $2 \mathbf{a}-\mathbf{f}$ than $N$-acetylglycine. Global hardness $(\eta)$ is another parameter used to guesstimate relative reactivity of molecules. A harder molecule (higher value of $\eta$ ) is generally less reactive (Soayed et al., 2015; Fleming, 1976). The results in Table 6 also showed that 1 (Nacetylglycine) is harder than the derived products $(\mathbf{2 a}-\mathbf{f})$, which is in agreement with the higher antimicrobial activities of the latter. Furthermore, 2a-falso exhibit lower dipole moment that $\mathbf{1}(\mathrm{N}$ acetylglycine), which suggests that the activity of the molecules against E. coli (-ve) and Ps. aeruginosa (-ve) might be favoured by low dipole moment. Both $\mathbf{2 a}$ and $\mathbf{2 f}$ that showed the highest inhibitive action against E. coli (-ve) also possess zero HBD. All the molecules $(\mathbf{2} \mathbf{a}-\mathbf{f})$ have lesser HBD than $N$ acetylglycine. This observation suggests that the activity of the compounds against the bacteria might have some dependency on the number of hydrogen bond donors present in the molecule.

Table 5. Quantum chemical parameters of the studied compounds

\begin{tabular}{llllllllll}
\hline $\begin{array}{l}\text { Parameters } \rightarrow \\
\text { Compounds } \downarrow\end{array}$ & $\begin{array}{l}\mathbf{E}_{\text {Hомо }} \\
(\mathbf{e V})\end{array}$ & $\begin{array}{l}\mathbf{E}_{\mathbf{L U M O}} \\
(\mathbf{e V})\end{array}$ & $\begin{array}{l}\Delta \mathbf{E} \\
(\mathbf{e V})\end{array}$ & $\begin{array}{l}\eta \\
(\mathbf{e V})\end{array}$ & $\begin{array}{l}\mu \\
(\text { Debye) }\end{array}$ & $\log \mathbf{P}$ & $\alpha$ & HBD & HBA \\
\hline $\mathrm{C} 141$ & -7.31 & -0.96 & 6.34 & 3.17 & 6.15 & -1.46 & 49.05 & 2 & 3 \\
$\mathrm{C} 142 \mathrm{a}$ & -6.03 & -2.50 & 3.53 & 1.77 & 2.34 & 0.37 & 60.64 & 0 & 4 \\
$\mathrm{C} 142 \mathrm{~b}$ & -6.26 & -2.62 & 3.64 & 1.82 & 3.31 & 1.09 & 56.75 & 1 & 3 \\
$\mathrm{C} 142 \mathrm{c}$ & -6.43 & -2.86 & 3.57 & 1.78 & 2.86 & 0.80 & 58.99 & 1 & 4 \\
$\mathrm{C} 142 \mathrm{~d}$ & -6.40 & -2.84 & 3.56 & 1.78 & 2.91 & 1.13 & 60.49 & 1 & 4 \\
$\mathrm{C} 142 \mathrm{e}$ & -6.48 & -3.04 & 3.43 & 1.72 & 3.72 & 1.06 & 58.27 & 1 & 3 \\
$\mathrm{C} 142 \mathrm{f}$ & -6.10 & -2.63 & 3.47 & 1.74 & 0.15 & 1.10 & 62.88 & 0 & 5 \\
\hline
\end{tabular}


The dependence of antimicrobial activity of the synthesized compounds on composite physical or quantum chemical parameters was investigated by developing some quantitative structure activity relationship (QSAR) model equations. The use of multiple linear regression (MLR) analysis in correlating biological activity of organic molecules to their molecular structures and electronic parameters is very popular in drug design (Fassihi et al., 2009; Deeb et al., 2007; Mandloiet al., 2005; Rasuleyet al., 2005; Hemmateenejad et al., 2002; Lien et al., 1999). If carefully developed, QSAR (MLR) models can be successfully used to predict biological activity of molecules (Mandloi et al., 2005; Hemmateenejad et al., 2002).

In the present study, acceptance of the QSAR equations was based on the level of reproducibility of experimental zone of inhibition (ZI) such that the mean square error (MSE) and root mean square error (RMSE) between the predicted zone of inhibition $\left(\mathrm{ZI}_{\text {Pred }}\right)$ and experimental zone of inhibition $\left(\mathrm{ZI}_{\mathrm{Exp}}\right)$ must be minimized and the correlation coefficient between $\mathrm{ZI}_{\text {Pred }}$ and $\mathrm{ZI}_{\text {Exp }}$ must approach unity. The quantum chemical descriptors utilized in the development of MLR models are those that showed some levels of relationship based on oneby-one correlations described in Table 5 .

The results of the QSAR analysis are summarized in Table 6 and Figure 1. The results in Table 6 suggest that the average zone of inhibition of the synthesized compounds against E. coli (-ve) and Ps. aeruginosa (-ve) strongly depend on $\mathrm{E}_{\text {номо }}, \mathrm{E}_{\mathrm{LUmo}}$, dipole moment $(\mu), \log P$, hardness $(\eta)$, and polarizability $(\alpha)$. The plot of $\mathrm{ZI}_{\text {Exp }}$ vs. $\mathrm{ZI}_{\text {Pred }}$ (Figure 1) reveals a strong correlation between the predicted and experimental values. It could be proposed that a combination of four parameters $\left(\mathrm{E}_{\text {номо }}, \mu, \log \mathrm{P}\right.$ and $\eta$ ) could be sufficient to predict relative antimicrobial activities of this family of compounds. The dependency of ZI on these parameters is such that a molecule with high $\mathrm{E}_{\text {номо, }}$ small $\mu$, small $\log \mathrm{P}$ and small $\eta$ values will exhibit relatively strong activity against $E$. coli (-ve) and Ps. aeruginosa (-ve).

Table 6. Descriptors and derived QSAR models**

\begin{tabular}{|c|c|c|c|c|}
\hline Descriptors & QSAR Equations & $\mathbf{R}^{2}$ & MSE & RMSE \\
\hline $\mathrm{E}_{\mathrm{HOMO}}, \eta, \mu, \log \mathrm{P}$ & $\mathrm{ZI}_{\text {pred }}=28.747+1.490 \mathrm{E}_{\text {HOMO }}-2.106 \eta-0.238 \mu-1.236 \log \mathrm{P}$ & 0.977 & 0.088 & 0.297 \\
\hline $\begin{array}{l}\mathrm{E}_{\text {HOMO }}, \mathrm{E}_{\text {LUMO }}, \mu, \\
\log \mathrm{P}\end{array}$ & $\mathrm{ZI}_{\text {pred }}=28.650+2.526 \mathrm{E}_{\mathrm{HOMO}}-1.044 \mathrm{E}_{\mathrm{LUMO}}-0.236 \mu-1.224 \log \mathrm{P}$ & 0.976 & 0.092 & 0.304 \\
\hline $\begin{array}{l}\mathrm{E}_{\text {HOMо, }} \mathrm{E} \text { симо, } \mu, \\
\log \mathrm{P}, \alpha\end{array}$ & $\mathrm{ZI}_{\text {pred }}=27.777+2.511 \mathrm{E}_{\mathrm{HOMO}}-0.978 \mathrm{E}_{\mathrm{LUMO}}-0.211 \mu-1.195 \log \mathrm{P}-0.015 \alpha$ & 0.976 & 0.183 & 0.428 \\
\hline
\end{tabular}

${ }^{* *} M S E=\sqrt{\sum_{i=1}^{N}\left(Z I_{\text {pred }}-Z I_{\text {exp }}\right)^{2}} ; R M S E=\sqrt{\frac{1}{n} \sum_{i=1}^{N}\left(Z I_{\text {pred }}-Z I_{\text {exp }}\right)^{2}}$ where $Z \mathrm{I}_{\text {pred }}$ is the predicted zone of

inhibition, and $\mathrm{ZI}_{\text {exp }}$ is the experimental zone of inhibition.

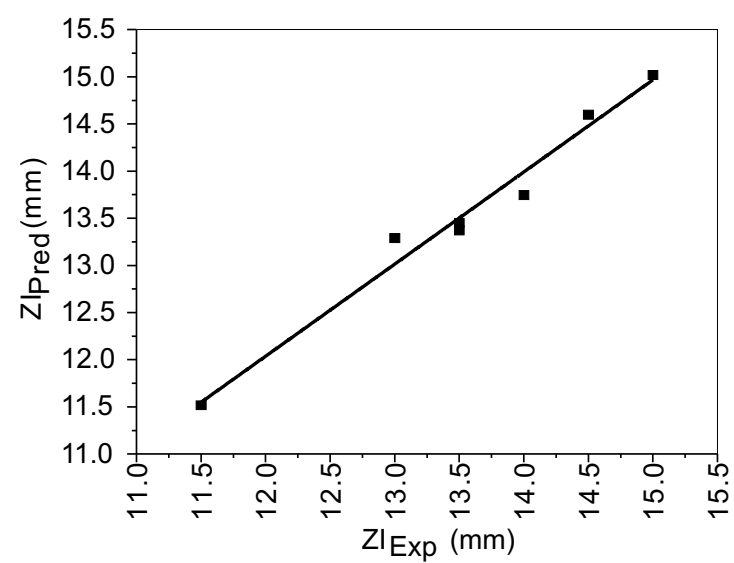

Figure 1. A typical plot of experimental and predicted zones of inhibition. 


\section{CONCLUSION}

Some oxazolone derivatives have been successfully synthesized in moderate to good yields and evaluated for inhibitory activities against ten bacterial and five fungal strains. Some of the synthesized compounds were found to have moderate to good activity against the tested microorganisms with compound $2 \mathrm{e}$ showing better activity against Escherichia coli and Streptococcus pneumonia than ampicillin. The enhancement of the activity of compound $2 \mathrm{e}$ could be attributed to the presence of a bromogroup on the phenyl ring. None of the compounds was active against the tested fungal strains. Theoretical quantum chemical calculations used to corroborate experimental studies revealed that the antibacterial activities of the compounds could be predicted from the QSAR empirical equations comprising $\mathrm{E}_{\text {номо }}$ $\mathrm{E}_{\mathrm{LUMO}}$, dipole moment $(\mu), \log \mathrm{P}$, hardness $(\eta)$, and polarizability $(\alpha)$. The predicted activities correlate well with experimental results.

\section{REFERENCES}

Aaglawe, M. J., Wakte, P.S. and Shinde, D. B. (2003).Synthesis and antibacterial activity of some oxazolone derivatives. Journal of the Korean Chemical Society 47(2), 133-136.

Abdel-Aty, A. S. (2009). Pesticidal effects of some imidazolidine and oxazolone derivatives. World Journal of Agricultural Sciences 5(1), 105-113.

Addinsoft, XLSTAT (2016.02), http://www.xlstat.com, 2016.

Akinpelu, D.A. and Kolawole, D.O. (2004). Phytochemical and antimicrobial activity of leaf extract of Piliostigmathonningii (Schum.). Science Focus Journal7: 64-70.

Alam, M. S., Liu, L., Lee, Y. E., and Lee, D. U. (2011).Synthesis, antibacterial activity and quantum-chemical studies of novel 2arylidenehydrazinyl-4-arylthiazole analogues. Chemical and Pharmacentical Bulletin 59(5), 568-573.

Alcaraz, L. E., Blanco, S. E., Puig, O. N., Tomas, F., and Ferretti, F. H. (2000).Antibacterial activity of flavonoids against methicillinresistant Staphylococcus aureus strains. Journal of Theoretical Biology 205(2), 231240.

Argade, N. D., Kalrale, B. K., and Gill, C. H.
(2008). Microwave assisted improved method for the synthesis of pyrazole containing 2, 4,-disubstituted oxazole-5one and their antimicrobial activity. Journal of Chemistry 5(1), 120-129.

Becke, A. D. (1993). Density-functional thermochemistry. III. The role of exact exchange. The Journal of Chemical Physics 98(7), 5648-5652.

Bhattacharjee, A. K., Skanchy, D. J., Jennings, B., Hudson, T. H., Brendle, J. J., and Werbovetz, K. A. (2002). Analysis of stereoelectronic properties, mechanism of action and pharmacophore of synthetic indolo $[2,1-b]$ quinazoline- 6,12 dione derivatives in relation to antileishmanial activity using quantum chemical, cyclic voltammetry and 3-DQSAR catalyst procedures. Bioorganic and Medicinal Chemistry 10(6), 1979-1989.

Brovarets, O.H., Zhurakivsky, R. O., \& Hovorun, D. M. (2014). Does the tautomeric status of the adenine bases change upon the dissociation of the $A^{*}$. A synTopal-Fresco DNA mismatch? A combined QM and QTAIM atomistic insight. Physical Chemistry Chemical Physics 16(8), 3715-3725.

Bourotte, M., Schmitt, M., Follenius-Wund, A., Pigault, C., Haiech, J., \& Bourguignon, J. J. (2004). Fluorophores related to the green fluorescent protein. Tetrahedron Letters 45(33), 6343-6348.

Brownlee, G., \& Woodbine, M. (1948). The antibacterial activity of some synthetic compounds related to penicillin. British Journal of Pharmacology 3(4), 305-308.

Cushnie, T. P. T., Hamilton, V. E. S., Chapman, D. G., Taylor, P. W., and Lamb, A. J. (2007). Aggregation of Staphylococcus aureus following treatment with the antibacterial flavonolgalangin. Journal of Applied Microbiology 103(5), 1562-1567.

Deeb, O., Hemmateenejad, B., Jaber, A., Garduno-Juarez, R., and Miri, R. (2007). Effect of the electronic and physicochemical parameters on the carcinogenesis activity of some sulfa drugs using QSAR analysis based on genetic-MLR and genetic-PLS. Chemosphere 67(11), 2122-2130. 
Desai, N. C., Bhavsar, A. M., and Baldaniya, B. B. (2009).Synthesis and antimicrobial activity of 5-imidazolinone derivatives.Indian Journal of Pharmaceutical Sciences 71(1), 90.

Dibetsoe, M., Olasunkanmi, L. O., Fayemi, O. E., Yesudass, S., Ramaganthan, B., Bahadur, I., and Ebenso, E. E. (2015). Some phthalocyanine and naphthalocyanine derivatives as corrosion inhibitors for aluminium in acidic medium: Experimental, quantum chemical calculations, QSAR studies and synergistic effect of iodide ions. Molecules 20(9), 15701-15734.

Fassihi, A., Abedi, D., Saghaie, L., Sabet, R., Fazeli, H., Bostaki, G. and Sadinpour, H. (2009). Synthesis, antimicrobial evaluation and QSAR study of some 3-hydroxypyridine4-one and 3-hydroxypyran-4-one derivatives. European Journal of Medicinal Chemistry, 44(5), 2145-2157.

Fearnley, S. P., and Market, E. (2002). Intramolecular Diels-Alder reactions of $\mathrm{N}$-substituted oxazolones. Chemical Communications (5), 438-439.

Frisch, M. J., Trucks, G. W., Schlegel, H. B., Scuseria, G. E., Robb, M. A., Cheeseman, J. R., and Nakatsuji, H. Farkas, JB Foresman, JV Ortiz, J. Cioslowski, DJ Fox, Gaussian 09 (revision D. 01), Gaussian Inc. Wallingford CT (USA) 2009. Google Scholar.

Fleming, J. (1976) Frontier Orbitals and Organic Chemical Reactions, John Wiley and Sons, New York.

Gaenzler and Corbo F. (2007). Part I. A 2nitroimidazole indocyanine green dye derivative tumor imaging agent. Part II. A dichlorination-reductive-dechlorination route to $N$-acetyl-2-oxazolone. Part III. Intramolecular Diels-Alder approach to the synthesis of pancratistatin. ProQuest and Dissertations Theses, AAT 3289509, pp. 163.

GonzÁlez-DÍaz, H., and Prado-Prado, F. J. (2008). Unified QSAR and network-based computational chemistry approach to antimicrobials, part 1: Multispecies activity models for antifungals. Journal of Computational Chemistry 29(4), 656-667.

Hemmateenejad, B., Miri, R., Akhond, M., \&
Shamsipur, M. (2002). QSAR study of the calcium channel antagonist activity of some recently synthesized dihydropyridine derivatives. An application of genetic algorithm for variable selection in MLR and PLS methods. Chemometrics and Intelligent Laboratory Systems 64(1), 91-99.

Irobi, O. N., Moo-Young, M., Anderson, W. A., and Daramola, S. O. (1994). Antimicrobial activity of bark extracts of Brideliaferruginea (Euphorbiaceae). Journal of Ethnopharmacology, 43(3), 185190.

Jung, B., Kim, H., and Park, B. S. (1996). Photodecarbonylation of 2-phenyl-4alkylidene-5 $(4 \mathrm{H})$-oxazolones. Tetrahedron Letters 37(23), 4019-4022.

Khan, K. M., Mughal, U. R., Khan, M. T. H., Perveen, S., and Choudhary, M. I. (2006). Oxazolones: new tyrosinase inhibitors; synthesis and their structure-activity relationships. Bioorganic \& Medicinal Chemistry 14(17), 6027-6033.

Lee, C., Yang, W., and Parr, R. G. (1988). Development of the Colle-Salvetti correlation-energy formula into a functional of the electron density. Physical Review B, 37(2), 785.

Lien, E. J., Ren, S., Bui, H. H., and Wang, R. (1999).Quantitative structure-activity relationship analysis of phenolic antioxidants. Free Radical Biology and Medicine 26(3-4), 285-294.

Lipinski, C. A., Lombardo, F., Dominy, B. W., and Feeney, P. J. (2001).Experimental and computational approaches to estimate solubility and permeability in drug discovery and development settings1. Advanced Drug Delivery Reviews 46(1-3), 326.

Lozynski, M., Rusinska-Roszak, D., and Mack, H. G. (1998). Hydrogen bonding and density functional calculations: The B3LYP approach as the shortest way to MP2 results. The Journal of Physical Chemistry $A$ 102(17), 2899-2903.

Madkour, H. M. F. (2002). Simple one-step syntheses of heterocyclic systems from (4Z)-2-phenyl-4-(thien-2-ylmethylene)-1, 3 (4H)-oxazol-5-one.Chemical Papers 56, 
313-319.

Mandloi, D., Joshi, S., Khadikar, P. V., and Khosla, N. (2005). QSAR study on the antibacterial activity of some sulfa drugs: building blockers of Mannich bases. Bioorganic \& Medicinal Chemistry Letters 15(2), 405-411.

Mesaik, M. A., Rahat, S., Khan, K. M., Choudhary, M. I., Murad, S., Ismail, Z., and Ahmad, A. (2004). Synthesis and immunomodulatory properties of selected oxazolone derivatives. Bioorganic \& Medicinal Chemistry, 12(9), 2049-2057.

Mokale, S. N., Lokwani, D. K., and Shinde, D. B. (2014). Synthesis, in-vitro reverse transcriptase inhibitory activity and docking study of some new imidazol-5one analogs. Medicinal Chemistry Research 23(8), 3752-3764.

Murthy, Y. L. N., Christopher, V., Prasad, U. V., Bisht, P. B., Ramanaih, D. V., Kalanoor, B. S., and Ali, S. A. (2010). Synthesis and study of nonlinear optical properties of 4substituted benzylidene-2-phenyl oxazol5 -ones by Z-scan technique. Synthetic Metals160(5-6), 535-539.

Ozturk, G., Alp, S., and Ergun, Y. (2007).Synthesis and spectroscopic properties of new 5oxazolone derivatives containing an $\mathrm{N}$ phenyl-aza-15-crown-5 moiety. Tetrahedron Letters 48(41), 7347-7350.

Ozturk, G., Alp, S., and Ertekin, K. (2007). Fluorescence emission studies of 4-(2furylmethylene)-2-phenyl-5-oxazolone embedded in polymer thin film and detection of $\mathrm{Fe}^{3+}$ ion. Dyes and pigments, 72(2), 150-156.

Ozturk, G., Alp, S., and Timur, S. (2008). Photophysical characterization of fluorescent oxazol-5-one derivatives in PVC and their application as biosensors in the detection of ACh and AChE inhibitor: Donepezil. Dyes and Pigments 76(3), 792798.

Palcut, M. (2009). Spectral Properties of Novel 1, 3-oxazol-5 (4H)-ones With Substituted Benzylidene and Phenyl rings. Acta Chimica Slovenica 56(2), 362-368.

Parr, R. G., and Yang, W. (1984).Density functional approach to the frontierelectron theory of chemical reactivity.
Journal of the American Chemical Society 106(14), 4049-4050.

Pasha, M. A., Jayashankara, V. P., Venugopala, K. N. and Rao, G. K. (2007). Zinc Oxide $(\mathrm{ZnO})$ : an efficient catalyst for the synthesis of 4-arylmethylidene-2-phenyl5- $(4 \mathrm{H})$-oxazolones having antimicrobial activity. Journal of Pharmacology and Toxicology 2, 264-270.

Pinto, I. L., West, A., Debouck, C. M., DiLella, A. G., Gorniak, J. G., O'Donnell, K. C., O'Shannessy, D. J., Patel, A. and Jarvest, R. L. (1996). Novel, selective mechanismbased inhibitors of the herpes proteases. Bioorganic \& Medicinal Chemistry Letters 6(20), 2467-2472.

Rasulev, B. F., Abdullaev, N. D., Syrov, V. N., and Leszczynski, J. (2005).A Quantitative Structure-Activity Relationship (QSAR) Study of the Antioxidant Activity of Flavonoids. Molecular Informatics 24(9), 1056-1065.

Rix, U., Rohr, J., Rix, L. L. R., Zheng, U. J. and Greenwell, L. (2004). The dynamic structure of Jadomycin B and the amino acid incorporation step of its biosynthesis. Journal of the American Chemical Society 126(14), 4496-4497.

Russell, A. D. and Furr, J. R. (1977). The antibacterial activity of a new chloroxylenol preparation containing ethylenediaminetetraacetic acid. Journal of Applied Bacteriology 43(2), 253-260.

Samijlenko, S. P., Yurenko, Y. P., Stepanyugin, A. V., and Hovorun, D. M. (2010).Tautomeric equilibrium of uracil and thymine in model protein- nucleic acid contacts. Spectroscopic and quantum chemical approach. The Journal of Physical Chemistry B, 114(3), 1454-1461.

Sánchez, C., Méndez, C. and Salas, J. A. (2006). Indolocarbazole natural products: occurrence, biosynthesis, and biological activity. Natural Product Reports 23(6), 10071045.

Schnettler, R.A., Jones, W.D. and Claxton, G.P. Cardiotonic heterocyclic oxazolones, United States Patent, Patent No: US 4698353 , Oct. 6, 1987.

Siddiqui, I. R., Singh, P. K., Srivastava, V., and Singh, J. (2010). Facile synthesis of acyclic 
analogues of carbocyclic nucleoside as potential anti-HIV pro-drug. Indian Journal of Chemistry, 49B, 512-520.

Siddiqui, S. A., Bhusare, S. R., Jarikote, D. V., Pawar, R. P. and Vibhute, Y. B. (2001). New novel synthesis and antibacterial activity of 1-(substitutedphenyl)-2phenyl-4-(3'-halo, 4'-hydroxy-5'methoxybenzylidene)-imidazole-5-ones. Bulletin-Korean Chemical Society 22(9), 10331036.

Sierra-Perron, F. M., Pierre, A., Burbridge, M., and Guilbaud, N. (2002).Novel bicyclic oxazolone derivatives as anti-angiogenic agents. Bioorganic \& Medicinal Chemistry Letters 12(11), 1463-1466.

Soayed, A. A., Refaat, H. M., and Sinha, L. (2015).Syntheses, structural elucidation, thermal properties, theoretical quantum chemical studies (DFT) and biological studies of barbituric-hydrazone complexes. Journal of Saudi Chemical Society
19(2), 217-226.

Tikdari, A. M., Fozooni, S., and Hamidian, H. (2008). Dodecatungstophosphoric acid (H3PW12O40), samarium and ruthenium(III) chloride catalyzed synthesis of unsaturated 2-phenyl-5 $(4 \mathrm{H})$ oxazolone derivatives under solvent-free conditions. Molecules 13(12), 3246-3252.

Witvrouw, M., Pannecouque, C., De Clercq, E., Fernández-Alvarez, E. and Marco, J. L. (1999). Inhibition of Human Immunodeficiency Virus Type (HIV-1) Replication by some diversely functionalized spirocyclopropyl derivatives. Archiv der Pharmazie 332(5), 163-166.

Wodrich, M. D., Corminboeuf, C., Schreiner, P. R., Fokin, A. A., and Schleyer, P. V. R. (2007). How accurate are DFT treatments of organic energies? Organic letters 9(10), 1851-1854. 